\title{
Exploring The Causes Of Suicide Incidents (With Firearm/Gun Shot) And Its Impact On Society: A Case Study Of Sindh Province Pakistan
}

\author{
Muhammad Afzal \\ Department of Law \\ University of Karachi
}

\begin{abstract}
The ratio of suicide incidents is increasing in males and females; many reasons are coupled with such incidents, to be discussed in this research article. My research is limited to Sindh Province, Pakistan. The Pakistan Penal Code, (1860) does not recognize or defines the definition of suicide, as an offense punishable under the respective offense. The wisdom behind is that the person who commits the suicide dies, the wrongful act of person also dies with the wrong doer. The ratio is more in youngsters, so, in this alarming situation, we are losing our young talented precious lives, it is not the loss of individual but whole society including our homeland (Pakistan), for the reasons that the persons those who committed suicide could have been our today's Businessman, Economists, Scientists, Engineers, Doctors and Experts in their respective fields, includes other professionals or common persons of the society. Keeping in view increasing rate of suicide incidents, it has become mandatory to save the loss of society. The suicide is massive menace for the developing society, an analytical study is conducted on such incidents for exploring the reasons, and particularly protective and precautionary measures are suggested for taking the practical steps in the province and to implement the law in letter in sprits. The study will serve larger interest of the public and would help in eradicating self- homicide incidents this, recommendations will address the problems. The stake holders of this province and Federal Government of Pakistan may cater and redress with this recurring issue in the light of recommendations.
\end{abstract}

Keywords: Causes, Firearm, Gunshot, Strangulation, Burning, Drowning, Poisoning, Injecting, Suicide, Impact, Society, Eradication, Gender.

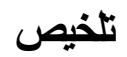

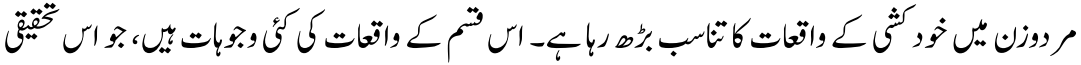

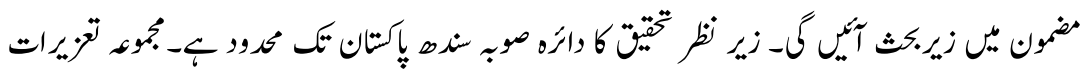

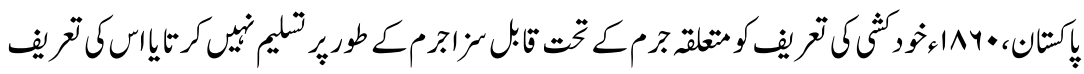

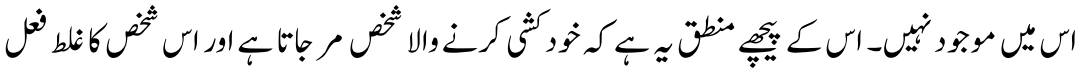

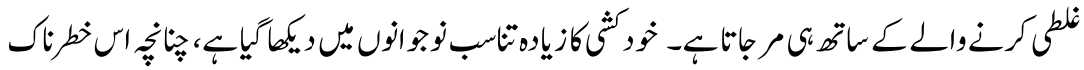




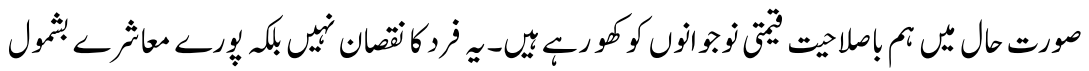

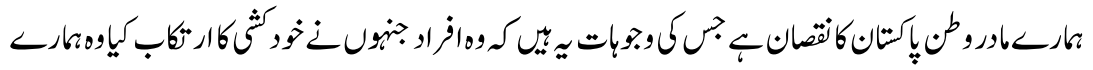

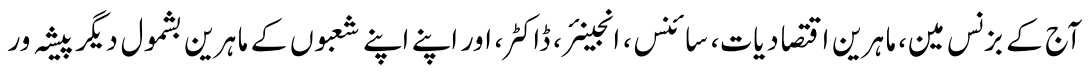

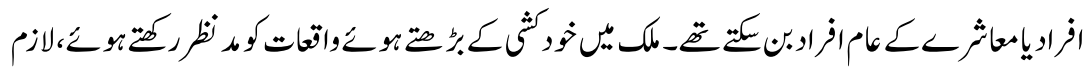

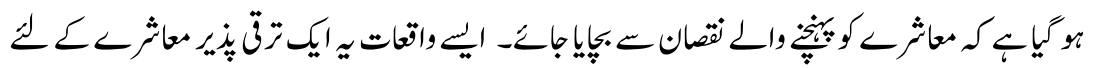

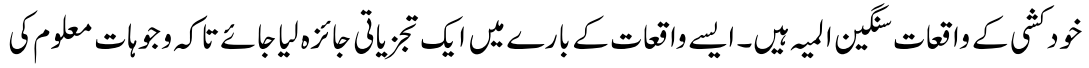

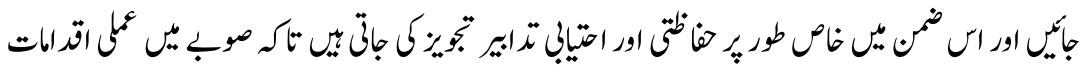

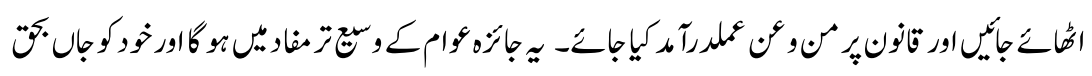

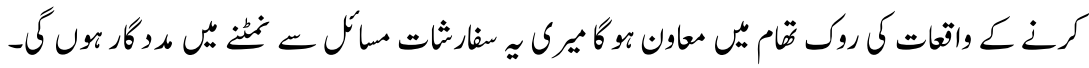

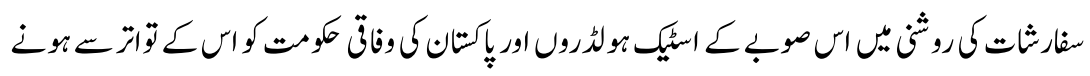

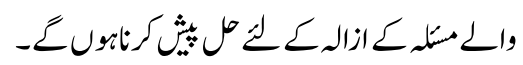

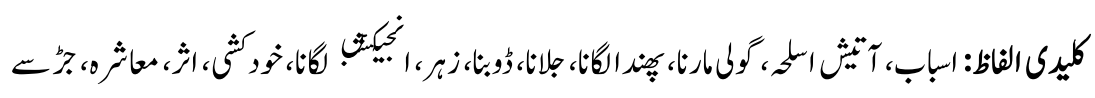

$$
\begin{aligned}
& \text { خاتم، منت }
\end{aligned}
$$

\section{Introduction}

The research in hands has wide scope in society, the increasing ration of suicide ${ }^{1-7}$, it needs proper attention. The objectives are protecting our prime youth talent as well as elders. So that they play their pivotal role and perform their duties in the society like a responsible citizen. The reports ${ }^{8}$ of the suicide and other cases are scrutinized by the public prosecutors under the prosecution laws ${ }^{9}$ the defense counsel need not be added as party, but the Medico Legal Officers are taken as respondents for conducting research from these participants.

The research under title is limited to the suicide incidents reported by different means but only committed with firearm (gunshot) ${ }^{10}$ in Sind Province it brings a bad impact on society, the reasons are collected by means of questionnaires. The results are discussed analytical and statically method in the light of results, the recommendations and suggestions are given in the conclusion.

The suicide ${ }^{11}$ is commonly found in every age group viz. teen agers ${ }^{12-15}$, elders in age of fifty $\&$ above. The rate of suicide in males has enhanced as compared to gender (females) ${ }^{16-18}$. The cases of suicide and attempt to commit suicide are also reported from all over the world, certain reasons and root causes still needs to be addressed, as the Sindh Province of Pakistan is also not free from this type of evil ${ }^{19}$. Many researchers have conducted the work and have given suggestions for eradicating the suicide menace. 
There are many types of desperate suicide Viz. strangulation ${ }^{20-21}$, poisoning, drowning and suicide with gunshot, as reported from media in Sindh Province (Pakistan) and world at large. Whereas an act of attempt to commit suicide is an offense as punishable under the Pakistan penal law $^{22}$. The present research is based on the questionnaires formulated in respect manner and assessment of ratio and results comes out by survey data analysis. The database collected from published research reports, articles, law journals, newspapers, magazine, monthly law digests of reputable legal institutions. The comparative study of Sindh province is made with other provinces of Pakistan and international case scenario. The study indicators will suggest for reducing or limiting the incidents by taking future precautionary steps. If not completely eradicated this menace of suicide from society, its impact will be on the youth generation of Pakistan (Sindh Province) collectively and ultimately, it is the loss of world at large as per U.N.O declaration the loss of one person (life) is presumed the loss of world.

\section{Review of Literature}

It is fact that no court is free from the incidents of the suicide with gunshot wounds or by other means, its most disgust act of the person with self-homicide, hence, the world religions ${ }^{23-27}$ strictly forbids to commit suicide with gunshot wound, there are many indicators reflecting a motive behind an intentional suicide (taking of one's own life). The range of wound can be near contact 1. c.m from the skin with hand guns called near contact shotgun wound entry. Whereas in intermediate entry wound it may be a few centimeters up to several feet, at the distant range, it may be any distance beyond that which produces stippling ${ }^{28}$.

There may be anti-suicide legislation or on attempt to commit suicide, but yet needs to be implemented, in reformative ways. The role of stake holders seems to be silent to implement the existing laws particularly with regard to the survivors who attempted attempt to commit suicide, the relevant laws are discussed for sake of brevity. It provides that rules are framed for guidance of the magistrates to try the cases, fixation of time and places of sitting, manner of conducting raids and trial on the spot, the cases wherein attempt to commit suicide is appeared/ registered, it is offence for which Magistrate courts have jurisdiction to try the same $^{29}$.

The provision provides investigation into cognizable cases, wherein, investigating officer without order of magistrate investigate any matter which is non-bailable within local area. The local magistrate has also conferred powers U/S 173, 190 \& 192 to Order for such investigation, further inquiry, transfer investigation and asking by police for remand and Orders on it and calling inquest report. The suicide offences also come in the ambit of inquest report for the purpose of ocular account of occurrence ${ }^{30}$. 
The provision of Section 174 Cr.P.C its clause-1 sub-clause (a) empowers the police to enquire on suicide etc, through the office incharge of a police station or some other police officer authorized by the provincial government in that behalf for receiving information regarding commitment of suicide ${ }^{31}$.

The police officer has the power to call two or more persons by issuing written order to proceed with 174 Cr.P.C proceedings for investigation, the persons (witnesses) must be acquainted with facts of the case ${ }^{32}$. The Magistrate is empowered $^{33}$ to disinter corps for conducting examination of death body of any person already buried in order to discover the cause of death ${ }^{34}$.

There is no time limit to disinterment ${ }^{35}$. Sometimes it happens that the dead bodies may requires exhumation for knowing the truth of the facts, through DNA tests and other autopsy procedure after death, to know the real cause of death permitted under the law for which law permits ${ }^{36}$. The expert helps in detecting nature of wound and diagnosing as whether homicide or suicide is committed by a person whose body is lying before the police officer ${ }^{37}$.

Article 59 provides an opinion of an expert, on the question of science or art of handwriting or finger impression, Electronic Transaction Ordinance 2002 are covered as evidence under the Qanoon-e-Shahadat $\operatorname{Order}^{38}$. Article 164 provides provisions for allowing the evidence available because of modern devices, the Hon'ble Court may allow such evidence viz. audio, video ${ }^{39}$, Compact Disk ${ }^{40}$, reports of electronic and print media ${ }^{41}$ and press clipping ${ }^{42}$.

The investigating officer is empowered ${ }^{43-44}$ to investigate any cognizable offence within the territorial limits of his jurisdiction ${ }^{45}$. The rules provide provision for investigating officer to dispense with a surgical examination of the body provided by law with the discretion, when the cause of death is established beyond doubt. In the nature of accidental cases which suggests no reason to suspects that no reason of cause of death would suggest by sending matter to expert examination of the body apparently and examination of the body is liable to be dispensed with. Suspicion exists that the death was due either to suicide or to an act rendering the perpetrator thereof liable to a criminal charge the body must be examined by a qualified medical expert.

After the completion of investigation, the investigating officer shall draw up a report, in duplicate by the carbon copying process, in provided Form ${ }^{46}$ according as the deceased appears to have died ${ }^{47}$, in the instances as natural causes, by violence and poisoning. The report bearing apparent cause of death, description of any mark or marks of violence and the weapon or instrument marks used/inflicted in the incident. The report prepared by the police officer / conducting the investigation and other officials / persons during the investigation got recorded 
statements and such report shall be forwarded without delay through the Superintendent to the District Magistrate/Sub-Divisional Magistrate.

The following documents may form a part of Police inquest report:

As making plan of the scene of death, the inventory of clothing, etc., preparing list of the articles found nearby or on the body, and at the time of sent for medical examination preparation of a list of articles is to be sent for medical examination. In cases of death by hanging, the report shall give particulars as to the height and sufficiency of the support and the nature of the thing used to bear the weight of the body. Whereas in drowning cases the depth of the water shall be stated.

Carbon copy of such report (Challan) shall be filed in the police station in maintained register book ${ }^{48}$. A copy of all reports relating to deaths caused by railway accidents shall, when made by a police officer other than a railway police officer, be forwarded to the Assistant Inspector-General, Government Railway Police. The post-mortem examination is held by an expert and qualified surgeon as provided in criminal law ${ }^{49}$.

In cases of suicidal, homicidal, accidental or suspicious causes and where any doubt exists as to the exact cause of death, or if it appears to the officer conducting the investigation - whether under section 157 or section 174, Code of Criminal procedure - expedient to do so, the body shall be sent to the nearest medical officer authorized by the Local Government to conduct post-mortem examination. The sending of bodies of examination may only be dispensed with on the grounds of advanced putrefaction, which would clearly make examination useless. Power of investigating officer by law to dispense with a surgical examination of the body when the cause of death is established beyond doubt.

It is requirement of the law that the body shall be sent to the nearest qualified medical officer, and the orders of the Local Government prohibit the summoning of such officer to conduct his examination at or near the scene of the death save in exceptional cases. These may occur, where, owing to advanced putrefaction or the circumstances in which the corpse was found, movement of the corpse may make it impossible for the medical officer to form a correct opinion as to the nature of the injuries or the exact cause of death. In such cases if the investigating officer considers expert postmortem expeditious means available to the Superintendent of Police or Gazetted Officer in charge of the case, with a request that a qualified officer shall be sent to the absence of District Magistrate from headquarters to give orders for the medical examination of the body at the scene of death.

When it is impossible to send a body to a qualified medical officer for examination by medical officer on the spot, then investigating officer may, request 
the nearest Government medical officer to conduct post mortem examination, to assist him with his anatomical and other expert knowledge in estimating the effects and causes of injuries, etc. Such medical officers are not empowered to perform any operation on the body. Medical officers of the Irrigation and Public Health Departments and of local bodies cannot be called upon in this connection unless they have been specially authorized by the Local Government to undertake the medico-legal work ${ }^{50}$.

The medical officer having completed his examination of the person, body, or article shall record in full the result arrived at and in the case of a post mortem examination, is opinion as to the cause of death. He shall also record a list of any articles which he may intend to send to the Chemical Examiner. The report shall be written on the back of, or attached to form 25.39(1) and shall contain such reference to the person or object examined as will leave no possible doubt as to which case the remarks apply ${ }^{51}$. The report shall be placed with the police file of the case and may be used by the medical officer to refresh his memory when giving evidence.

Action to be taken by police. - When corpses are sent for medical examination the following rules shall be observed: -

The result of the investigating officer's examination of the body shall be carefully recorded in form 25-39(1). Clothing found on the body, foreign matter adhering to it and any instrument likely to have caused death remaining in a wound or on the body shall be secured in the position in which found, if possible, or, otherwise, shall be carefully packed separately ${ }^{52}$, according to the instructions contained in rules.

To counteract decomposition as far as possible the body shall be sprinkled with Formalin diluted to $10 \%$ and shall also be so used with strong solution of chloride of lime in water. Bodies which have to be carried long distances should be sprinkled with the dry powder of chloride of lime or with carbolic powder sold commercially in tin boxes with a perforated lid specially constructed for sprinkling purposes. The use of powdered charcoal is prohibited, as the stains caused thereby may complicate the task of post-mortem examination.

The transportation of body/litter for post mortem and procedure must be followed, the body is to be kept on a charpoy or other light litter and protected from the sun, flies and exposure to the weather. The investigating officer may deem expedient in the circumstances of weather, distance to be covered and conditions of the body. The motor vehicle may be hired which is more expedient conveyance, to carry the corpse and those who are required to accompany it as escort or witnesses. Expedition of the transportation of dead bodies for medical examination by the police officers. 
Two police officers who have seen the dead body in the position in which it was first found, and are competent to detect any attempt at substitution or tampering with the body or its coverings, shall accompany the body to the mortuary, and remain in charge of it until examination is complete. If necessary an additional guard shall be supplied by the Lines Officer to places sentry on the mortuary, but the officers who have accompanied the body from the sport shall hand it over personally to the medical officer conducting the post-mortem examination together with all reports and articles sent by the investigating officer to assist the examination and shall receive and convey to the investigating officer the postmortem report.

Upon completion of medical examination of the body by the Civil Surgeon, he intimates the police and the police may hand make over to the deceased's relatives or friends or, if there are no relatives or friends, or they decline to receive it, the police shall cause the body to be buried or burnt according to the rules framed in this behalf by the District Magistrate.

The courts have to see the compulsion and constraints, mitigating ${ }^{53}$, circumstances in suicide cases. In Pakistan attempt to commit suicide is an offence, any person who attempts to commit suicide act is punishable with simple imprisonment for a term which may extend to one year or with fine or with both ${ }^{54}$.

The post mortem and pathologist report is the more effective in the cases of the suicide, the cause of death and operating procedure, nature of injuries and description of the offences. The attempt to commit suicide is also an offense. Hence it, determines that that whether it was suicide or the homicide or any intentional criminal act of injuries.

Section-509 of Cr.P.C provides the provision for calling medical witness to conduct postmortem of the body (the person who committed suicide), the civil surgeon or doctor is summoned to give evidence in presence of accused before the court $^{55}$.

When the persons commit suicide, the cause of death is necessary to be find out through medical expert doctor, the time of arrival, bio-data of victim, nature of injuries, receipt of body source, particulars of the crime, internal and external condition of the victim body. The study of medical jurisprudence suggesting specific firearm injuries, main precautions and procedure in conducting autopsy, then handing over of the body to legal heirs, issuance of postmortem report and medical certificate bearing cause of death alongwith specifications of death, date, time of arrival and departure of body. 
A post mortem, also known as an autopsy, is an important medical examination that aims to find out more about a person's last illness and the cause of their death $^{56}$. There are two types of post-mortem: Post-mortem examinations required by Coroners. These are investigations required by law and do not require the agreement of relatives. Consented post-mortems, which are requested by doctors or by relatives. Full signed agreement must be given by the relatives for this type of post-mortem to be carried out. Relatives can make limitations for this type of post-mortem. A consented post-mortem cannot take place without the agreement of the next-of-kin. If you agree to a Consented post-mortem examination the doctors will issue the medical certificate of death before the post-mortem so that you can proceed with the arrangements for the funeral ${ }^{57}$.

The nature of injury suggest the weapon used in suicide, which injury cause more fatal which caused the death of victim. In attempt to commit suicide injury of firearm wounds suggest for assessing the guilt of accused to award him punishment. Section-59 of Qanoon-e-Shahadat Order bears provision for recording fingerprint system, it helps with the opinion of expert to identify the recording of prints left by the persons who committed the suicide and it helps in matching prints on the weapon used in suicide or attempting to commit the same $^{58}$.

While discussing the further objects of the study it is expedient and mandatory to protect our prime youth talent as well as elders. So that they play their pivotal role and perform their duties in the society like a responsible citizen. The reports ${ }^{59}$ of the suicide and other cases are scrutinized by the public prosecutors ${ }^{60}$, the defense counsel need not be added as party, but the Medico Legal Officers are taken as respondents for conducting research from these participants.

The research under title is limited to the suicide incidents reported ${ }^{61}$ by different means but only committed with firearm (gunshot) in Sind Province it brings a bad impact on society, the reasons are collected by means of questionnaires.

\section{Methodology}

i. Primary and secondary data is collected to analyses the problem.

ii. Questionnaires were prepared and distributed among cream of the society well educated category, legal fraternity viz. Doctors, Advocates and Prosecutors personals.

iii. Depression, psychological, socio economic impact is assessed.

iv. The medical and expert reports are perused to see the symptoms difference of entry and exit wounds of suicide cases.

v. The reasoning is abstracted from the questionnaires, discussion/results. 
vi. Living standards, poverty, lake of education are areas having impact with the title of the research.

vii. Many forms of suicide were incorporated in questionnaires, where from some cases are highlighted from the local newspapers such as daily Dawn, the Jang News, the Tribune, the News, daily Jang and also in daily kawish.

\section{Participants}

The 60 (sixty) questionnaires 10 questionnaires were allocated for each division in the highly educated persons among the participants' viz.-doctors, advocates and public prosecutors belonging to different walks of life were included to find the reasons of research problem. Data collected is based upon their opinions.

\section{Procedure}

Participants were approached at their places; the purpose of the study was explained to them. All the respondents filled the informed consent; it took 14 to 15 minutes to fill out the questionnaires.

\section{Discussion}

These wounds may be usually medically adjudicated as more irregular, in shape than the entry wounds, these wounds does not show soot deposition, muzzle imprint, stippling, or blackening of the skin edges. The shored exits wounds are which wherein, the skin is in contact with another object, when the bullet exits, this causes an irregular area of abrasion on the skin, which can be confused with the abrasion ring of an entrance wound.

The pathology out lines provides forensic types of injuries, like gunshot wounds in suicide cases which are committed with firearm reflects, muzzle is pressed against the skin, when fired, it may be abdominal or chest, can be observed as circular wound with blackened, the margins of skin appearing seared particularly in the areas of lose skin.

The medical information may be not perfect, it is intended for physicians and qua person, its interpretation needs to be interpreted case to case very as per history, disease, pain, chemical data of a patient, the medical forensic science assists in forming the reasonable medical judgment.

So, the suicidal cases are commonly caused by contact with skin or head, where the scalp is tight cover the skull, entry wounds can have several different appearances viz: round wound with blackened, seared skin margins, stellate shaped wound, for tearing of skin from expanding gas dissecting between the 
scalp and skull with muzzle imprint, also due to gas expanding under the skin causing it to press back against the gun.

The survey of cases shows that most of the suicides are committed over petty matters and silly reasons as mentioned in this research paper. This can be found in every age groups teenager, married person's category 35 to 45 and above agers. The reasons of committing suicide are different as per distinctly allocated ages:

\section{The Reasons of Suicide in Teenagers}

i. The teenager (male + female) commits suicide for tiny things viz. Pocket money or things not provided by the parents, emotional love, affairs, when their wishes of unarranged marriages are not fulfilled by parents.

ii. The frequent use of toys manufactured in shape of gunshots in childhood makes a continuing habit of using a fire-arm.

iii. Isolation of children by parents to teenage boys and girls.

iv. Watching of fighting and horror movies becomes resort to know moot operating of firearm weapon.

v. Sometimes parents, school teachers scold the child and the child commits suicide due to access or availability of the firearm at home or any other place.

vi. Failure in study admissions, examination and bad results in colleges/ for higher studies.

\section{Suicide in Age Group of 25 to 45 Years}

i. The research indicates that poverty is the main cause for committing suicide, this happens particularly in an age group of twenty-five to forty-five years age.

ii. This age group of persons commits suicide due to domestic disputes within family and outside the family and non-matching of marriages contracts are also reasons for suicide.

iii. The unemployment is also main cause of the suicide, large family members are depending on one hand earning member who couldn't support and went in depression, and the man becomes psychiatric patient and then commits suicide to get rid of all problems.

The deferent reports and data is collected from the published and on line information cited on respective web sites showing the record.

The other reasons in age group of 45 and above are as under;

i. Disputes over property ownership.

ii. Fear of survival, uncertainty for bad economic conditions.

iii. Law and order situation leads to depression. 
iv. Homeless persons having no shelter.

v. In marriages the menace of delivery of dowry articles demand by groom side from bride party when it is not fulfilled marriage contract proposal stands canceled on score of non-providing dowry articles, it leads women to commit suicide.

vi. Delivery of women in Wata Sata, Badla-e-Sulah (Jirga) or forced arbitration.

vii. Some incidents are reported that firstly man commits murder then takes his life.

\section{Results}

The data was analysed on the basis of study objectives. The demographic details of the participants were also included.

Keeping in view above scenario questions were prepared \& distributed among participants Respondents/for reaching on right and just conclusion of the research.

Table Showing the Ratio and Percentage of Research Title Results on Questionnaires among 20 each (Doctors, Advocates \& Prosecutors)

\begin{tabular}{|c|c|c|c|c|c|c|c|c|c|c|c|c|c|c|c|c|c|c|c|c|}
\hline \multirow{2}{*}{$\begin{array}{l}\text { Question } \\
\text { No. }\end{array}$} & \multicolumn{5}{|c|}{20 Doctors $(33.3 \%)$} & \multicolumn{5}{|c|}{20 Advocates $(33.3 \%)$} & \multicolumn{5}{|c|}{20 Prosecutor $(33.3 \%)$} & \multicolumn{5}{|c|}{ Total Average } \\
\hline & \begin{tabular}{|c|}
$\mathrm{a} /$ \\
True
\end{tabular} & $\begin{array}{c}\mathrm{b} / \\
\text { False }\end{array}$ & $\mathrm{c}$ & $\mathrm{d}$ & $\mathrm{E}$ & $\begin{array}{c}\mathrm{a} / \\
\text { True }\end{array}$ & \begin{tabular}{|c|}
$\mathrm{b} /$ \\
False
\end{tabular} & $\mathrm{c}$ & $\mathrm{d}$ & $\mathrm{E}$ & $\begin{array}{c}\text { a/ } \\
\text { True }\end{array}$ & $\begin{array}{c}\mathrm{b} / \\
\text { False }\end{array}$ & $\mathrm{C}$ & $\mathrm{d}$ & $E$ & $\mathrm{a} /$ true & \begin{tabular}{|c|}
$\mathrm{b} /$ \\
False
\end{tabular} & $\mathrm{c}$ & $\mathrm{d}$ & $\mathrm{E}$ \\
\hline Q. 1. & 8 & 2 & 8 & 2 & 0 & 7 & 3 & 8 & 2 & 0 & 8 & 2 & 7 & 3 & 0 & 7.66 & 2.33 & 7.66 & 2.33 & 0 \\
\hline Q.2. & 10 & 5 & 4 & 1 & 0 & 9 & 5 & 4 & 2 & 0 & 11 & 4 & 4 & 1 & 0 & 10 & 4.66 & 4 & 1.33 & 0 \\
\hline Q.3. & 3 & 12 & 3 & 2 & 0 & 4 & 10 & 3 & 3 & 0 & 2 & 12 & 3 & 3 & 0 & 3 & 11.3 & 3 & 2.66 & 0 \\
\hline Q. 4. & 4 & 9 & 4 & 3 & 0 & 3 & 10 & 4 & 3 & 0 & 5 & 9 & 3 & 3 & 0 & 4 & 9.33 & 3.66 & 3 & 0 \\
\hline Q. 5. & 0 & 0 & 0 & 0 & 20 & 0 & 0 & 0 & 0 & 20 & 0 & 0 & 0 & 0 & \begin{tabular}{|l|}
20 \\
\end{tabular} & 0 & 0 & 0 & 0 & 20 \\
\hline Q. 6. & 5 & 7 & 5 & 3 & 0 & 5 & 6 & 6 & 3 & 0 & 6 & 8 & 4 & 2 & 0 & 5.33 & 7 & 5 & 2.66 & 0 \\
\hline Q. 7. & 0 & 0 & 0 & 0 & 20 & 0 & 0 & 0 & 0 & 20 & 0 & 0 & 0 & 0 & 20 & 0 & 0 & 0 & 0 & 20 \\
\hline Q. 8. & 0 & 0 & 0 & 0 & 20 & 0 & 0 & 0 & 0 & 20 & 0 & 0 & 0 & 0 & 20 & 0 & 0 & 0 & 0 & 20 \\
\hline Q. 9. & 6 & 7 & 3 & 4 & 0 & 6 & 7 & 3 & 4 & 0 & 5 & 9 & 3 & 3 & 0 & 5.66 & 7.66 & 3 & 3.66 & 0 \\
\hline Q. 10. & 0 & 0 & 0 & 0 & 20 & 0 & 0 & 0 & 0 & 20 & 0 & 0 & 0 & 0 & 20 & 0 & 0 & 0 & 0 & 20 \\
\hline Q. 11. & 13 & 3 & 2 & 2 & 0 & 11 & 4 & 2 & 3 & 0 & 12 & 3 & 2 & 3 & 0 & 12 & 3.33 & 2 & 2.66 & 0 \\
\hline Q. 12 . & 0 & 0 & 0 & 0 & 20 & 0 & 0 & 0 & 0 & 20 & 0 & 0 & 0 & 0 & 20 & 0 & 0 & 0 & 0 & 20 \\
\hline Q. 13. & 3 & 11 & 3 & 3 & 0 & 4 & 10 & 3 & 3 & 0 & 4 & 12 & 2 & 2 & \begin{tabular}{|l|}
0 \\
\end{tabular} & 3.66 & 11 & 2.66 & 2.66 & 0 \\
\hline Q. 14. & 7 & 2 & 2 & 3 & 6 & 6 & 3 & 2 & 3 & 6 & 7 & 2 & 4 & 2 & 5 & 6.66 & 2.33 & 2.66 & 2.66 & 5.66 \\
\hline Q. 15. & 1 & 5 & 2 & 2 & 10 & 2 & 4 & 2 & 2 & 10 & 1 & 6 & 0 & 2 & 11 & 1.33 & 5 & 1.33 & 2 & 10.3 \\
\hline Q. 16. & 18 & 0 & 1 & 1 & 0 & 17 & 1 & 1 & 1 & 0 & 19 & 0 & 0 & 1 & 0 & 18 & \begin{tabular}{|l|}
0.33 \\
\end{tabular} & 0.66 & 1 & 0 \\
\hline Q. 17. & 19 & 0 & 1 & 0 & 0 & 18 & 0 & 1 & 1 & 0 & 19 & 0 & 1 & 0 & 0 & 18.6 & 0 & 1 & 0.33 & 0 \\
\hline Q. 18. & 9 & 4 & 3 & 4 & 0 & 9 & 3 & 4 & 4 & 0 & 10 & 4 & 3 & 3 & 0 & 9.33 & 3.66 & 3.33 & 3.66 & 0 \\
\hline Q. 19. & 0 & 0 & 0 & 0 & 20 & 0 & 0 & 0 & 0 & 20 & 0 & 0 & 0 & 0 & 20 & 0 & 0 & 0 & 0 & 20 \\
\hline Q. 20. & $100 \%$ & & & & & $100 \%$ & & & & & $100 \%$ & & & & & $100 \%$ & & & & \\
\hline Q. 21. & $50 \%$ & $50 \%$ & & & & $50 \%$ & $50 \%$ & & & & $50 \%$ & $50 \%$ & & & & $50 \%$ & $50 \%$ & & & \\
\hline Q. 22 . & $50 \%$ & $50 \%$ & & & & $50 \%$ & $50 \%$ & & & & $50 \%$ & $50 \%$ & & & & $50 \%$ & $50 \%$ & & & \\
\hline Q. 23. & $50 \%$ & $50 \%$ & & & & $50 \%$ & $50 \%$ & & & & $50 \%$ & $50 \%$ & & & & $50 \%$ & $50 \%$ & & & \\
\hline Q. 24. & $100 \%$ & & & & & $100 \%$ & & & & & $100 \%$ & & & & & $100 \%$ & & & & \\
\hline Q.25. & $50 \%$ & $50 \%$ & & & & $50 \%$ & $50 \%$ & & & & $50 \%$ & $50 \%$ & & & & $50 \%$ & $50 \%$ & & & \\
\hline
\end{tabular}

\section{Results Discussion on the Respondents/ Participants out Put on Research Questionnaires}

The aims of the study was to explore the reasons hence every questions results are interpreted as under: 
The Question No. 1, reflects that suicides are committed by means of strangulation and poisoning more than the other means and secondly ratio of committing the same with firearm.

In Question No. 2, the age group has importance to identify the ages in whom apprehension of committing suicide appears to be highest in response, respondents opted the age group of 14-19 more than the other age groups.

The Question No. 3, is also responsive to examine risk of committing suicide and its probability, it was found foremost in teen ager male is more risk than in teen ager females and it is less in male \& female adults.

In Question No. 4, in finding causes of suicide the august reason is found depression and secondly poverty and on third socioeconomic effect and finally psychological problems.

The Question No. 5, is pertaining to reduction in suicide incidents, the equal response found in all cases, if the suggested methods on the people be applied so that could be refrain from committing the same.

In Question No.6. That the respondents / participants prescribed first aid rehabilitation centers are necessary for those who survived from attempting to commit suicide or in depression aftermath of incident, the respondents suggested that rehabilitation centers firstly be established at taluka levels then at UC levels and then in districts/divisions.

In Question No.7, in other reasons, isolation and depression is also main factor, upon which respondents fixed the liability equally on all stake holders.

The Question No. 8, reflects that the poverty and unemployment are also main reasons for committing or attempt to commit suicide, respondents equally distributed the factors as mentioned in question.

In Question No. 9, the medical and forensic science has also main role to find distance of firearm gunshot in suicide is mostly actuated/realized, respondents posed that 7.66 person as near contact muzzle held at short distance from skin 1 c.m, secondly with Contact Muzzle passed with skin with ratio of 5.66 persons, thirdly Distance beyond that which produces stippling with ratio of 3.66 persons and finally Intermediate from few c.m's up to several feet with ratio of 3 persons total out of 20 persons from each group. 
The Question No. 10, the respondents equally opted and assigned the ration that suicidal offences their nature, type of entry wounds are categorized based on range, options as mentioned in the question.

In Question No. 11, the nature of exit wounds of gunshot appears in committing suicide the respondents opted that $t$ object when the bullet exists, this causes an irregular area of abrasion on the skin.

The Question No. 12, the respondents gave equal response for symptoms of gunshot wound on skull (Shajjah) sustained for committing suicide, the bone appears in all options.

In Question No. 13, the incidents of suicide are in areas of Sindh, Pakistan 11 persons told that in rural areas, 3.66 persons told that in urban areas, then 2.66 persons equally told that theses happen in hilly and deserted areas.

The Question NO. 14, reflects that which division is mostly affected participants the respondents opted in Sukkur with percentage of 6.66 persons, then the 5.66 ratio of persons in Karachi, then 2.66 ratio of persons in Larkana and Mirpurkhas and finally ratio of 2.33 persons told in Hyderabad divisions.

In Question No. 15, the ratio of suicide is more common told by 10.3 persons told in each group, 5 persons in children, 2 persons in orphans and 1.33 persons told in each male female adults.

The Question No. 16, reflects that attempt to commit suicide is offence under the P.P.C 186018.6 told yes and ratio of 2 persons were unaware about the offence related to the attempt to commit suicide.

In Question No. 17. As the 18.6 persons out of 20 were aware about the punishment of attempt to commit suicide as one year and 1.4 persons were unaware.

The Question No.18, the disparity among the jobless adults reported due to unemployment in society (Sindh Province) can be the probable factor for which respondents opted as 9.33 persons told yes in adults of age group 40-50 (male), 4 persons have chosen male adults below 40 and 4 have chosen only in children and 3.33 persons told that ratio in only females who are below 40 years.

In Question No. 19, minor children commit suicide over patty matters for no role is played by each category in options all respondents/ participants held responsible. 
In Question No. 20, that do you think that psychologist and Medical officer is necessary for consultation and mind therapy at initial stage of depression followed by suicide? All respondents told true.

The Question No. 21, Liability of suicide can be fixed on parents? In children case. $50 \%$ told true.

The Question No. 22 that in adults case liability can be fixed on Government due to unemployment. $50 \%$ told true.

The Question No. 23, that the laws are not implemented and lake of awareness are the main reasons for attempt to commit suicide. $50 \%$ told true.

The Question No. 24, The Suicide is not punishable but attempt to commit suicide is an offence under the Pakistan Penal Code, 1860. All told true.

The Question No. 25, the drugs and narcotics substance users have more chances of attempt to commit suicide. $50 \%$ told true.

In the month of January 10,2020, show that only as far as Sindh is concerned, Mirpur Khas Division is increased, heading over all other divisions as compared to earlier survey above on Divisional based, the division where the highest number of suicide incidents occurred in the last five years, and 646 people killed themselves with their own hands. Of them, 356 were women and 290 were men ${ }^{62}$.

\section{Conclusions}

The present study as concluded that in this alarming situation, increasing ratio of suicide through different modes in piecemeal during the last decade harmful in the particular teen agers, there is acute need of awareness by means of viz. awareness through media and printed material, implementation of laws, eradication of poverty, establishing more rehabilitation institutions at district levels for the affected and depressed persons for their early recovery, getting conducted their psychotherapy tests. The psychological factors as depression, poverty, unemployment and disappointment can be removed by applying positive methods, all these are mandatory solutions to save the persons and make them a good citizen like others.

\section{Recommendations}

The study was conducted on divisional cities bases by seeking opinion form the persons who are the cream of the society levels, As I found that more deeply and intensive study/ investigation needs to be conducted on the problem being faced 
by the persons of the society or finding just solution, however it is here by recommended as under:

1. Keeping firearm away by owners from the innocent children in house.

2. Government may establish centers at every Taluka, U.C, District and then Divisional levels for depressed patients/or in hospitals one unit may be allowed to be established such type of patients.

3. The parents' eye watch is also mandatory on their children for not letting them placed at isolated place/homes, parents must fulfil the needs and demands of their children.

4. Role of the Schools, Colleges, University teachers, must be emphasized to keep supervision on the students and report the same symptoms and activities to their respective parents.

5. The activities of the students residing at hostels of the students must be checked so that they may be saved at an early stage of depression symptoms.

6. The old citizens having depression, the stress involved in such dilemma be admitted to hospital psychiatric ward. For their proper health care.

7. The Pakistan Penal Code (1860) and the Code of Criminal Procedure 1898, suggests meaning and manner of the suicide offence in Courts for trial.

8. The research suggests to put ban on manufacturing and selling of toys in shape of Fire-Arms holding in the hands by innocent children, from their early age they learn how to operate a firearm (Gunshot). The fighting with toys in shape of firearm streets of cities and towns on every ceremonial day, and so also learning to emitted from the movies, these films may not be allowed to children or censored.

9. In gender the females are mostly affected by domestic violence, work place harassment, family disputes between spouse qua family members, disputes over ownership of things and property belongs to women, deprivation of their rights are also main reasons for committing suicide with a firearm.

10. The treatment through speech therapy in holy mosques and temples and holy prayers places of world religions necessary for eradicating the evil of suicide which is very unpleasant to the Almighty Allah and teachings of world religion.

11. The psychologist and experts suggest for medical assistance for depressed persons due to continuous stress and depression leads the man and women life to a close Street, for taking their own lives voluntarily.

12. Parents, teachers and specifically government stake holders are responsible for not taking pre-measures, precautionary steps it is necessary to keep engage affected persons with some sound and healthy activities so that they may come out from the problems and their lives could be saved. 
13. Use of drugs/narcotics substance, these circumstances also leads the children men or women to commit suicide with a firearm in such drunken condition of narcotic substance, in such scenario/circumstances, the drugs and narcotics substance must be kept away from children and persons.

14. The circumstances being faced by the victim, deceased, reasons are the compulsion which needs or causes such thought in the mind of affected, external and internal affairs, behaviour of persons with the incumbent could not be ignored, no proper redressal of children grievance by the parent, friends and so closed persons even secondary liability can be fixed on teachers the most manifest liability comes upon the government for not heeding attention to the socio-economic of the citizen lost by the country.

15. In suicide, weapon lies with the victim and in homicide weapon is taken away by the accused person.

16. There is always the probability that in suicide cases weapons are found licensed but in homicide, it may not appear.

17. The attempt of suicide is punishable but when the suicide offence is completed it is not punishable.

\section{End Notes}

1. Daily Newspaper "The News" https://www.thenews.com.pk/print/596397rising-suicide-tendencies-in-sindh-over-1-300-ended-their-lives-in-5-yearsretrieved on 13-02-2020

2. The News Paper "The Daily Express Tribune" $>$ Pakistan $>$ Sindh -Girl commits suicide after shooting sister in Shikarpur-Girl commits suicide after shooting sister in Shikarpur-By Our Correspondent-Published: January 30, 2017-SUKKUR: A 14-year-old girl, committed suicide on Sunday, two days after she accidentally shot her elder sister, while playing with their father's gun, in Shikarpur. htpp://tribune.com.pk. Retrieved on22, feb, 2017.

3. (2017) The Newspaper Daily the Express Tribune- Pakistan -Motive Unknown: Young man commits suicide in HARIPUR htpp://tribune.com.pk- January 21, 2017

4. (2017) By Arsalan Altaf, The Newspaper Daily the Express Tribune, it has been reported that "Student kills himself in school over "infatuation with teacher' in Islamabad-Student kills himself in school over 'infatuation with teacher' in Islamabad-By Arsalan Altaf- avilable on htpp://tribune.com.pk. January 17, 2017 -

5. (2017) Female student found dead in Sindh University hostelhtpp://tribune.com.pk Published: January 3, 2017- in Hyderabad, a student's death - the possibility of suicide is being considered - in a girls' hostel of the Sindh University (SU) has mystified the academia, her family and the people concerned with the varsity. 
6. (2017) Majid Maqsood The Newspaper Daily the Express Tribune OPINION- LETTERS-Student murder-suicide case-Student murder-suicide case-By Letter- htpp://tribune.com.pk. January 8, 2017

7. (2016) The Newspaper Daily the Express Tribune -Drastic Measures: Minor commits suicide over squabble -Drastic Measures: Minor commits suicide over squabble -By Our Correspondent-Published: December 14, 2016KARACHI: A minor girl allegedly committed suicide on Wednesday. Twelve-year-old $\mathrm{H}^{*}$ committed suicide by hanging herself from a ceiling fan in her house in Korangi.- htpp://tribune.com.pk, Published in The Express Tribune, December 15th, 2016.

8. Section 173 Code of Criminal Procedure, 1868. http://pakistancode.gov.pk/ english/index- http://www.molaw.gov.pk/ (in local and National language it is also called Challan)

9. Section 09-"Powers of the Prosecutors to Scrutinize the Challan" The Sindh Criminal Prosecution Service (Constitution, Functions and Powers) 2013 and ibid (Amendment) Act, 2015 Sindh Act NO. II OF 2016. Available at Website. sindhlaws.gov.pk > departmentcode. Search Resultssindhlaws.gov.pk $>$ sindhindex

10. (2020) By Yusra Salim / Photo: Aysha Saleem-Published: September 2, 2015-(A teenage boy shot a girl and then himself on the premises of Gulshan-e-Fatima school in Soldier Bazaar Karachi on Tuesday morning). Retrieved from website on January, 21, 2020.

11. Section 25 of the Pakistan Penal Code, 1860. http://pakistancode.gov.pk/ english/index- http://www.molaw.gov.pk/

12. (2017) The Newspaper Daily the Express Tribune-LETTERS-Student murder-suicide case-Student murder-suicide case-By Letter-Published: January 8, 2017-Majid Maqsood-Published in The Express Tribune, January 9th, 2017.

13. (2017) In the Newspaper Daily the Express Tribune -Motive Unknown: Young man commits suicide-Motive Unknown in Chijaka village, Suicide: Young man commits suicide -By Our CorrespondentPublished: January 21, 2017-HARIPUR: Published in The Express Tribune, January 21st, 2017.

14. (2017) In the Newspaper Daily the Express Tribune-SINDH-Girl commits suicide after shooting sister in Shikarpur-Girl commits suicide after shooting sister in Shikarpur-Published: on January 30, 2017-Sukkur: "A 14-year-old girl, committed suicide on Sunday, two days after she accidentally shot her elder sister" while playing with their father's gun, in Shikarpur. Published in The Express Tribune, htpp://tribune.com.pk January 30th, 2017

15. (2016) In the Newspaper Daily the Express Tribune -Drastic Measures: Minor commits suicide over squabble-Drastic Measures: Minor commits suicide over squabble-By Our Correspondent-Published: December 14, 2016-KARACHI: A minor girl allegedly committed suicide on Wednesday. 
Twelve-year-old $\mathrm{H}^{*}$ committed suicide by hanging herself from a ceiling fan in her house in Korangi.- htpp://tribune.com.pk -Published in The Express Tribune, December 15th, 2016.

16. (2017) In the Newspaper Daily the Express Tribune-SINDH-Girl commits suicide after shooting sister in Shikarpur-Girl commits suicide after shooting sister in Shikarpur-By Our Correspondent-Published: January 30, $2017-$ SUKKUR: A 14-year-old girl, $\mathrm{F}^{*}$, committed suicide on Sunday, two days after she accidentally shot her elder sister, $\mathrm{K}^{*}$, while playing with their father's gun, in Shikarpur. Published in The Express Tribune, htpp://tribune.com.pk January 30th, 2017

17. (2016) In the Newspaper Daily the Express Tribune -Drastic Measures: Minor commits suicide over squabble -Drastic Measures: Minor commits suicide over squabble -By Our Correspondent-Published: December 14, 2016-KARACHI: A minor girl allegedly committed suicide on Wednesday. Twelve-year-old $\mathrm{H}^{*}$ committed suicide by hanging herself from a ceiling fan in her house in Korangi.- htpp://tribune.com.pk -Published in The Express Tribune, December 15th, 2016.

18. (2020) The report dated January 10, 2020, show that only As far as Sindh is concerned, Mirpur Khas is the division where the highest number of suicide incidents occurred in the last five years, and 646 people killed themselves with their own hands. Of them, 356 were women and 290 were men. https://www.thenews.com.pk/print/596397-rising-suicide-tendencies-insindh-over-1-300-ended-their-lives-in-5-years (retrieved on 13-02-2020)

19. (2017) It is reported in the Newspaper Daily the Express Tribune -"Motive Unknown: Young man commits suicide " htpp://tribune.com.pk-Published in The Express Tribune, January 21, 2017.

20. (2017) Daily dawn News Paper https://www.dawn.com/news/1306787Suspect arrested in 'suicide' case of Sindh University student a 'repeat offender': police-Ali Hasan, January 06, 2017. Retrieved on August 24, 2017.Read with The Tribune daily newspaper. Preliminary report confirmed signs of strangulation on his neck by a rope; however, a detailed chemical report will elaborate on the cause. Published on June 22, 2012 -the express tribune. Retrieved on August 24, 2017.

21. (2017) The Tribune daily newspaper reported by Umer Nagiana. https://tribune.com.pk/story/397410/another-suicide-university-studentfound-hanged-in-hostel-room/. Published on Published: June 22, 2012. Retrieved on August 24, 2017.

22. Section 325 of Pakistan Penal Code, 1860. The Pakistan Code http://pakistancode.gov.pk/english/index. Retrieved on 13-02-2020.

23. Do not kill or destroy yourself. (Quran: 4:29) -Islam forbids suicide. Man is the vicegerent of Allah on earth and he who commits suicide runs away 
from his obligation to Allah. Make not your own hands contribute to your destruction. (11.195)

24. By, Hassan Masudul Prof., (1983) the Digest of Holy Quran at p-416. Law Publishing Company Katchery road Lahore (Pakistan), April 4,1983.

25. Al-Quran:-“And do not kill yourselves. Surely, God is Most Merciful to you." (Al-Quran 4:29) retrieved from https://quran.com/2/195 February 13, 2020-“And do not throw yourselves in destruction." (Al-Quran 2:195) Retrieved from and https://quran.com/4/29- retrieved on February 13, 2020. The Quran: "O you who have believed, let not a people ridicule [another] people; perhaps they may be better than them; nor let women ridicule [other] women; perhaps they may be better than them. And do not insult one another and do not call each other by [offensive] nicknames. Wretched is the name of disobedience after [one's] faith. And whoever does not repent - then it is those who are the wrongdoers." (Al-Quran 49:11)https://quran.com/49/11 retrieved on February 13, 2020.

26. Bible: "What? Know ye not that your body is the temple of the Holy Ghost which is in you, which ye have of God, and ye are not your own? For ye are bought with a price: therefore, glorify God in your body, and in your spirit, which are God's" (1Corinthians 6:19-20). https://www.biblegateway.com/ passage $/$ ? search $=1+$ Corinthians $+6 \% 3 \mathrm{~A} 19-20 \&$ version $=\mathrm{KJV}$ (Retrieved on February 13, 2020).

27. Corinthians 10:31-"Reveal that the Holy Spirit dwells in those who are saved. It is our responsibility to treat Him with respect, and suicide is not appropriate. Genesis 1:26, 27 (and similar verses) reveal that we are made in the image of God. This is one of the reasons we are not allowed to murder (see Genesis 9:6,7), so again suicide would be a bad thing. The Bible teaches to trust, depend on, and believe in God throughout its length. (Romans 8:28 is one example.) To take your own life would show no faith in God. Notice that although the prophets, apostles, and Jesus Christ were persecuted, tortured, and put to death; they did not commit suicide for an "easy out." They "fought the good fight" to the end (see 2 Timothy 4:6-8). Be aware of how suicide affects other people's opinion of the person who died. It is common for people to wonder if someone who commits suicide went to heaven". http://www.clarifyingchristianity.com/suicide.shtml Retrieved on February 13, 2020.

28. Website accessed on -Firearm Injuries -Rifled Firearms vs Shot gunsForensic Medicine and Toxicology -http://howmed.net/forensic/firearminjuries-rifled-firearms-vs-shot-guns/http://www.slideshare.net/ananthatiger/forensic-medicine-firearms-andfirearm-injuries-6344130- and http://www.slideshare.net/dr.salhab/firearminjuries - Retrieved on 25-17-2017.

29. Section 34 of Code of Criminal Procedure 1898 -http://pakistancode.gov.pk/ english/index-http://www.molaw.gov.pk/ 
30. Sec.156 Code of Criminal Procedure 1898. http://pakistancode.gov.pk/ english/index- http://www.molaw.gov.pk/

31. Section 174 of ibid. http://pakistancode.gov.pk/english/indexhttp://www.molaw.gov.pk/.

32. Section 175 of ibid. http://pakistancode.gov.pk/english/indexhttp://www.molaw.gov.pk/

33. Sub-sect. (1) of Sect-176 of Cr.P.C 1998. http://pakistancode.gov.pk/english/index- http://www.molaw.gov.pk/

34. (1992) Pakistan Criminal Law Journal page 1870, (2010) Pakistan Criminal Law Journal page -4, (2010) Monthly Law Digest page 5, 2011 Pakistan Criminal Law Journal page .1287 and Pakistan Law Decisions 2014 Baluchistan page 50.

35. 1996 Pakistan Criminal Law Journal page 389.

36. Sub-Section 2 of Section 176 of Code of Criminal Procedure 1998. http://pakistancode.gov.pk/english/index- http://www.molaw.gov.pk/

37. Article 164 of Qanoon-e-Shahadat Order, 1984 (Pakistan). http://pakistancode.gov.pk/english/index-http://www.molaw.gov.pk/

38. 2005 Pakistan Criminal Law Journal page 228 and Pakistan Law Decisions PLD 2014 Bal. pp.113 and 114.

39. Pakistan Law Decisions PLD 2007 Karachi page 448.

40. 2008 Monthly Law Digest MLD page 1442.

41. Pakistan Law Decisions -P.L.D 2010 SC page 265.

42. Pakistan Law Decisions 2015 PLD Islamabad page 85.

43. Police Rule 1934 its Chapter-XXV, Rule- 25.35.

44. Sect.156, of Code of Criminal Procedure, 1898.

45. Rule 25.2 prescribes for empowerment of Investigation/Police Officers and their privileges, the details please are referring sections 160 to 175 in Cr.P.C 1898.

46. Form 25-35(1) A, B, or C Class Reports Provided in the Police Rules 1935.

47. The Rule 25-35 (1) A, B, or C provides Inquest Report Form Police Rules 1934.

48. Explanation- Register No. VI. Actually it is called Book, which is kept at police station for entry of the incident contents.

49. Rule 25-36. Of Police Rules, 1934-Read with Section 17(3), Code of Criminal Procedure 1898.

50. Vide Rule 25.19 of the Police Rules, 1934

51. Police Rules 1934-Rule-25.47, Report of medical officer and the report shall be written on the back of, or attached to Form -25.39(1)

52. The result of the investigating officer's examination of the body shall be carefully recorded in form Read with Rule 25-39(1) rule 25-41.

53. 2012 Yearly Law Reporter YLR Page 652.

54. Section 325 of Pakistan Penal Code 1860. http://pakistancode.gov.pk/english/index- http://www.molaw.gov.pk/. 
55. Section 509 of Code of Criminal Procedure 1898. http://pakistancode.gov.pk/english/index- http://www.molaw.gov.pk/.

56. https://www.google.com.pk/search?q=A+Procedure+of + Post + mortem + exa mination.

$\& \mathrm{rlz}=1 \mathrm{C} 1 \mathrm{CHZL}$ enPK755PK755\&oq $=\mathrm{A}+$ Procedure + of + Post + mortem + exa mination.\&aqs $=$ chrome..69i57j69i6412.2404j0j7\&sourceid=chrome\&ie=UT F-8. Accessed on 24-07-20017 on web site

57. Accessed on 24-07-20017 on web site https://www.google.com.pk/search?q=A+Procedure + of + Post + mortem+exa mination. \&rlz=1C1CHZL_enPK755PK755\&oq $=\mathrm{A}+$ Procedure + of + Post + mortem+examination.\&aqs $=$ chrome..69i57j69i6412.2404j0j7\&sourceid $=\mathrm{chr}$ ome \&ie $=\mathrm{UTF}-8$

58. Article 59 of Qanoon-e-Shahadat Order 1984 (Law of Evidence in Pakistan) available at http://pakistancode.gov.pk/english/indexhttp://www.molaw.gov.pk/

59. Section 173 of Code of Criminal Procedure, 1898. (in local national language it is also called Challan)http://pakistancode.gov.pk/english/indexhttp://www.molaw.gov.pk/

60. Section 09-The Sindh Criminal Prosecution Service (Constitution, Functions and Powers) (Amendment) Act, 2015 Sindh Act NO. II OF 2016.

61. (2015) By Yusra Salim / Photo: Aysha Saleem-Published: September 2, 2015-(A teenage boy shot a girl and then himself on the premises of Gulshan-e-Fatima school in Soldier Bazaar Karachi on Tuesday morning). The Express Tribune, accessed on August-2017 and Febraury,12 2020

62. (2020)"Daily the News Fri Feb 21, 2020" the ratio of suicide increases in Mirpukhas Division as compare to other divisionshttps://www.thenews.com.pk/print/596397-rising-suicide-tendencies-insindh-over-1-300- ended-their-lives-in-5-yearsRetrieved in February, 2020.

\section{References}

Al-Quran-available at website source- https://quran.com/2/195

"Firearm Injuries -Rifled Firearms vs shot guns" source-available on websiteretrieved on July 25, $2017 \mathrm{http} / / /$ howmed.net/forensic/firearm-injuriesrifled-firearms-vs-shot-guns/.

"Forensic medicine firearms and firearm injuries"- retrieved on July 25, 2017http://www.slideshare.net/ananthatiger/forensic-medicine-firearms-andfirearm-injuries-6344130

Code of Criminal Procedure 1898 Pakistan available on websitehttp://pakistancode.gov.pk/english/index- http://www.molaw.gov.pk/ 
Hasan, A. (January 06, 2017). Suspect Arrested in 'suicide' Case of Sindh University student a 'repeat offender': police, Daily Dawn. Retrieved on August 24, 2017 form https://www.dawn.com/news/1306787

Hassan. M. (1983). The Digest of Holy Quran Law Publishing Company, Lahore, Pakistan, p.416.

Monthly Law Digest (2008). PLD, Lahore.

Pakistan Legal Decisions (PLD) (2007, 2010, 2014 and 2015) available. PLD Publishers, Lahore, Pakistan.

Pakistan Penal, Code 1860-Available on websitehttp://pakistancode.gov.pk/english/index-

Police Rule 1934 available in High Court Karachi Sindh Bar Library at Karachi

Qanoon-e-Shahadat Order, 1984 available on websitehttp://pakistancode.gov.pk/english/index-

The Bible- available on website- retrieved (February 13, 2020) from https://www.biblegateway.com/passage/?search=1+Corinthians $+6 \% 3 \mathrm{~A} 19$ $-20 \&$ version $=\mathrm{KJV}$.

The Sindh Criminal Prosecution Service (2013). (Constitution, Functions and Powers) 2013 with -ibid-(Amendment) Act, 2015 Sindh Act NO. II OF 2016. Available on www.pas.gov.pk > index.php.

Muhammad Afzal is Ph.D Scholar in the Department of Law, University of Karachi, Karachi, Pakistan. 